\title{
Considering Geographies of Sexualities, Gender and Activism: An Interview with Professor Gavin Brown
}

\author{
Gilly Hartal
}

Bar-Ilan University (Israel). The Gender Studies Program

gilly.hartal@biu.ac.il

\section{Gavin Brown}

University of Leicester (UK). Department of Geography

gpb10@le.ac.uk

\begin{abstract}
Gavin Brown (University of Leicester, UK) is one of today's most eminent scholars of political geography and sexualities. In this intellectual-biographical interview, he describes his academic path, as well as discusses some of his major contributions to the fields of geographies of sexualities and gender and protest movements and activism. This interview by Gilly Hartal introduces some of his major conceptual and theoretical contributions in the fields of sexualities and gender, geopolitics, the spatiality of protest camps and, in particular, the spatial practice of solidarity. Knowledge, as feminist theory has taught us, is always grounded in personal-political contexts and subjectivities. This conversation with Gavin Brown offers an intimate perspective into Brown's academic experience, which interestingly also reflects the growth and materialization of the field of geographies of sexualities into a sub-discipline. The interview also addresses the current state of critical geographical work and calls for support of and solidarity with scholars and departments under threat.
\end{abstract}

Keywords: geographies of sexualities; homonormativity; protest camps; critical geographies; geopolitics of sexualities and gender 
Resum. Considerar les geografies de les sexualitats, el gènere i l'activisme: una entrevista al professor Gavin Brown

Gavin Brown (Universitat de Leicester, Regne Unit) és un dels acadèmics més eminents pel que fa a geografia política i sexualitats. En aquesta entrevista intel.lectual i biogràfica conduïda per Gilly Hartal, Brown hi descriu la seva carrera acadèmica i discuteix sobre les principals contribucions que ha fet en el camp de les geografies de les sexualitats i el gènere $\mathrm{i}$ en els moviments de protesta i l'activisme. L'entrevista presenta algunes de les seves aportacions en els àmbits de les sexualitats i el gènere, la geopolítica, l'espacialitat dels camps de protesta $i$, en particular, la pràctica espacial de la solidaritat. El coneixement, tal com la teoria feminista ens ha ensenyat, es fonamenta sempre en contextos i subjectivitats personals i polítiques. La conversa amb Gavin Brown ofereix una perspectiva íntima de l'experiència acadèmica de Brown i, al mateix temps, de manera molt interessant, mostra el desenvolupament i la materialització de les geografies de les sexualitats en una subdisciplina. L'entrevista també tracta sobre l'estat actual de la recerca en geografia crítica i reclama suport i solidaritat amb els investigadors i investigadores $\mathrm{i}$ amb els departaments sota amenaça.

Paraules clau: geografies de les sexualitats; homonormativitat; camps de protesta; geografies crítiques; geopolítiques de les sexualitats i del gènere

Resumen. Considerar las geografias de las sexualidades, el género y el activismo: una entrevista al profesor Gavin Brown

Gavin Brown (Universidad de Leicester, Reino Unido) es uno de los académicos más eminentes en el campo de la geografía política y las sexualidades. En esta entrevista intelectual y biográfica conducida por Gilly Hartal, Brown describe su carrera académica y discute sobre sus principales contribuciones en el campo de las geografías de las sexualidades y el género y en los movimientos de protesta y el activismo. La entrevista presenta algunas de sus aportaciones en los ámbitos de las sexualidades y el género, la geopolítica, la espacialidad de los campos de protesta y, en particular, la práctica espacial de la solidaridad. El conocimiento, tal como la teoría feminista nos ha enseñado, se fundamenta siempre en contextos y subjetividades personales y políticas. La conversación con Gavin Brown ofrece una perspectiva íntima de la experiencia académica de Brown y, a la vez, de manera muy interesante, muestra el desarrollo y la materialización de las geografías de las sexualidades en una subdisciplina. La entrevista también trata sobre el estado actual de la investigación en geografía crítica y reclama ayuda y solidaridad con los investigadores e investigadoras y con los departamentos bajo amenaza.

Palabras clave: geografías de las sexualidades; homonormatividad; campos de protesta; geografías críticas; geopolíticas de las sexualidades y del género

Résumé. Considérer les géographies des sexualités, du genre et de l'activisme: entretien avec le professeur Gavin Brown

Gavin Brown (Université de Leicester, Royaume-Uni) est l'un des plus éminents spécialistes de la géographie politique et des sexualités. Dans cet entretien intellectuel-biographique mené par Gilly Hartal, il décrit sa carrière universitaire et évoque ses principales contributions dans le domaine des géographies des sexualités et du genre, ainsi que des mouvements de protestation et de l'activisme. L'entretien présente certaines de ses contributions dans les domaines des sexualités et du genre, de la géopolitique, de la spatialité des champs de protestation, et en particulier de la pratique spatiale de la solidarité. La connaissance, 
comme nous l'a appris la théorie féministe, est toujours basée sur des contextes et des subjectivités personnels et politiques. La conversation avec Gavin Brown offre une perspective intime de l'expérience académique de Brown et montre en même temps, de manière très intéressante, le développement et la matérialisation des géographies des sexualités dans une sous-discipline. L'interview explique également l'état actuel de la recherche en géographie critique et appelle à l'aide et à la solidarité avec les chercheurs et les départements menacés.

Mots-clés: géographies des sexualités; homonormativité; champs de protestation; géographies critiques; géopolitique des sexualités et du genre

\section{Introduction}

Gavin Brown is one of today's most eminent scholars of political geography and sexualities. He is a Professor of Human Geography at the University of Leicester in the UK and an editor of Social and Cultural Geography. Gavin Brown's pioneering work addresses sexualities and gender, geopolitics, the spatiality of protest camps, and the spatial practice of solidarity in particular. In a number of widely cited publications, among them "Homonormativity: A metropolitan concept that denigrates 'ordinary' gay lives" (2012), he developed the theoretical concept of homonormativity, arguing that it is a collection of social changes across specific political constellations that produces particular consequences.

He co-edited Geographies of Sexualities (2007) with Kath Browne and Jason Lim, and The Routledge Research Companion to Geographies of Sex and Sexualities (2016) with Kath Browne as well. He has also edited or authored three other books: Protest Camps in International Context (2018), with Anna Feigenbaum, Fabian Frenzel and Patrick McCurdy; Youth Activism and Solidarity: the Non-stop Picket Against Apartheid (2017), with Helen Yaffe; and Singing for Our Lives: Stories from the Street Choirs (2018), as part of the Campaign Choirs Writing Collective.

Gavin Brown was a founding member of the Space, Sexualities and Queer Research Group of the Royal Geographical Society and has served as both its treasurer and chair. He was also part of the collective which initiated the European Geographies of Sexualities Conferences. He is interviewed here by Gilly Hartal from the Gender Studies Programme at Bar-Ilan University.

Gilly I'm interested in hearing about some of the formative influences upon you - What led you to choose the study of Geography as a student and specifically geographies of sexualities? Was there a thinker, an event, political or social that changed/influenced what you wanted to study?

Gavin Although I enjoyed geography at high school, I did not study Geography as an undergraduate. I originally did a degree in Fine Art (and while I learned a lot about myself in the process, one of the things it taught me was that I was never going to be more than a moderately talented amateur and that I was far better at exploring complex ideas in writing than visually). However, there are definitely continuities between the issues that interested me at art college and those that 
have persisted throughout my academic career. Then, as now, I was interested in queer lives, politics, and protest.

I didn't directly study in a university geography department until I started my $\mathrm{PhD}$ (although the supervisor for my MA dissertation was a geographer - Tim Butler - working, at that time, in a sociology department). Between graduating from my undergraduate degree and starting my MA, I worked in a low-grade administrative job at Queen Mary College in London. While I was working there, I got to know a number of postgraduate students, including David Woodhead, who was a PhD student in the geography department there at the time. When he published a chapter in Mapping Desire (Bell and Valentine, 1995) I bought a copy out of interest. It wasn't the first academic geography I had read - I'd certainly read Harvey's (1989) The Condition of Postmodernity during my undergraduate degree - but it totally captivated me and transformed my understanding of what geography was and how it could help me understand the world around me. In many ways that book came along at a time when I was becoming bored with the job I was doing and was yearning to get back to studying. The opportunity to do that did not come along for another couple of years, but during the intervening period, I spent a lot of my lunchtimes at work reading geography journals and queer theory in the university library. I read a lot of social and cultural geography at the time, but also sought out work that thought spatially about LGBT lives. Queers in Space (Ingram et al., 1997) was another very influential book for me around that time.

In the late 1990s, I was working at the University of East London, running their Admissions Office. Once I had passed my probationary period, I had the opportunity to take a part-time postgraduate course there for free. While I think my managers hoped I would do a management degree, I chose to do a MA by research, based in the sociology department with Tim Butler. My research focused on gay gentrification in East London. This drew on my reading of Mapping Desire, Queers in Space and other work of the time. What interested me was the visible presence of a large number of young gay professionals in the area where I lived. They were clearly participating in the gentrification of the area, but that process of gentrification had not yet completely changed the social character of the neighbourhood, so they lived alongside the remnants of an older, more working-class gay scene. I felt this was important to study as the area did not feel like the city centre 'gaybourhoods' being described in the literature in North American cities, or even Manchester and Central London. This work resulted in a number of my earliest publications (Brown, 2001; 2006) - which I tend to think of as quite basic, but am pleasantly surprised when they continue to be cited from time to time.

I think this early postgraduate work contained the hallmarks of an approach that I have returned to throughout my career - a sympathe- 
tic critique and challenge to emerging orthodoxies in the field, and a desire to test out whether those commonplace assumptions really stand up to scrutiny in other locations. But then I think an important aspect of academic geography is being sensitive to the way in which social phenomena vary geographically and are (re)shaped by specific spatial relationships.

Gilly Do you think there is a British/European distinct perspective? Do you think it animates your own work, in what ways?

Gavin That's a really interesting question! I think there definitely was a distinction between some of the early geographies of sexualities work coming out of the USA in the late 1980s and early 1990s compared to its British counterparts. A lot of the US work sought legitimacy by engaging with contemporary debates in urban geography (and, to some extent, political geography); the British work was very much part of the broader 'cultural turn' of the time. I think that meant that some of the early British work - and here I'm thinking particularly of work by David Bell (2001) and Jon Binnie $(1995 ; 1997)$ was more playful and more willing to engage with the messy materialities of queer sex. I'm not sure those distinctions are quite so clear-cut any more.

Having said that, there was a reason a group of us initiated the European Geographies of Sexualities conference(s) a decade ago. We felt that too many of the debates we (as, mostly, British and Irish geographers of sexualities) were engaged with looked across the Atlantic to agendas set in North America, at the expense of conversations with colleagues in the rest of Europe. But I think that was as much a consequence of the ways in which American academics dominate queer theory as it was about the academic discipline of geography. So, I think we felt that there was a danger that too many debates were being shaped by an intellectual US exceptionalism, and that the dynamics of sexual politics and LGBT lives were very different in European contexts. Lots of important theoretical contributions have been made by US and Canadian scholars. I don't want to dismiss their work at all. But I was, and remain, suspicious of a tendency to uncritically apply concepts developed in specific North American contexts to the rest of the world.

At the same time, it's fair to say that British geographies of sexualities work has been shaped by a whole set of theoretical debates and trends in British social and cultural geography. There are problems with overly aligning geographies of sexualities with (post-structuralist) social and cultural geography at the expense of an engagement with other sub-disciplines too. This is one of the reasons (despite my role as an editor of Social \& Cultural Geography) that I have been keen to explore new connections between geographies of sexualities and (heterodox) economic geography, political geography, critical 
and feminist geopolitics, and health geographies, for example. Our work should not be limited to a subset of one sub-disciplinary field, but should be an expansive field of study that cuts across many different areas of academic geography.

Gilly Natalie Oswin (2018) has noted that geographies of sexualities (LGBTphobia and patriarchy) are overlooked in the field of human geography. Specifically, she pointed to the need of urban geography to acknowledge sexualities (and gender) informed research. To some degree that's a reflection of the structure of rewards in academic and political institutions. However, is it possible that it is also conceptual? That is, urban geographies models seem to be constructed without taking sexualities into account, and 'inserting sexualities' then appears to be both difficult and unnecessary - is it a dialogue of the deaf, between sexualities scholars and those of traditional' geography?

Gavin I think Natalie is right. And, as the reactions to her critique have demonstrated, there are some male urban geographers who are very resistant and hostile to taking seriously the role of sexualities and gender in shaping urban life and urban space. I think you are right that social class and class struggle is foundational to a lot of critical urban geography. However, I wonder if some of this refusal to see sexualities is also a consequence of the development of geographies of sexualities, as a sub-discipline, over the last 25 years. As I noted above, geographies of sexualities have engaged with social and cultural geography (and, I think, largely been taken seriously there), but have engaged in less dialogue with urban geographers since the 1990s. Another issue is that geographies of sexualities, as a field, still largely examines LGBTQ lives (and, occasionally, the geographies of sex work), and does not do enough to critically examine heterosexualities. I think that, if we are to make a case for taking sexuality seriously in the production of urban space, then we need to examine a wider range of desires and intimacies, not just those of minority groups. In part, this is a problem we have inherited from queer theory. The slippage from a critique of normativity to a celebration of the non-normative does not really help in making a strong case for examining how sexualities of all kinds shape the city and urban life.

Gilly How in your opinion, can geographies of sexualities inform queer theory and construct theoretical knowledge outside the boundaries of geography? And more specifically, how can geographies of sexualities have wide influence on political and cultural theory?

Gavin I think that, because geography as a discipline encompasses such a wide range of work, from the hard-natural sciences right through to the geohumanities, geographers are often more open to interdisciplinary ideas and working methods than many other scholars. But this 
also means that we are intellectual 'magpies' and have a tendency to pick up shiny new ideas from all over the place. I strongly believe that we need to be more confident and assertive in demonstrating what geography and a critical geographical imagination can add to wider critical scholarship about sexualities. While some of this work will, inevitably, be in dialogue with 'queer theory' (just as much of my own work is), I also think we need to be wary of simply adding spatiality and an awareness of uneven geographies to queer theory. I think it would be a shame if the geographies of sexualities tradition simply reduced itself to being 'queer theory + space'. If we continue to do this, we continue to position ourselves as adjuncts to a different disciplinary tradition, rather than asserting real confidence in what geography can offer to a critical engagement with the world.

One of the reasons I have been using ideas from critical and feminist geopolitics in my work over the last few years has been precisely to explore the ways in which we can (re)start theorizing sexualities from a geographical perspective, rather than starting from queer theory and bringing it into geography. In doing this, I am not suggesting that only critical geopolitics can do this work. But I do think that starting from geographical concepts and debates might help us see and think about sexualities in different ways. For me queer theory has been useful, but it trains us to approach problems in particular ways, and I think that, for all its benefits, it also closes down other ways of seeing, and obscures some issues as much as it reveals others. I strongly believe that geographers of sexualities could be more confident in going out to the broader community of critical sexualities scholars and demonstrating the benefits of approaching issues from a critical geographical perspective. Let's move on from adding geographical nuance to queer theory and demonstrate to queer theorists why they might need to think geographically.

Gilly In some of your work within geographies of sexualities (2008; 2009; 2012; 2015) you argue that not only urban centres are homonormative, but that homonormativity is an assemblage of many practices, it stems from different locations. However, it is perceived, you argue, as a "global external entity that exists outside all of us and exerts its terrifying, normative power on gay lives everywhere" (2012: 1066).

It seems nowadays that the term 'homonormative' came to label any gay and lesbian political action vis-a-vis the state. Do you think this concept still has academic and theoretical currency? Can it open new ways of thinking about LGBT politics? Can you maybe clarify a bit more how different localities generate different homonormative and homonational practices?

Gavin I do think that Lisa Duggan (2002) was onto something when she identified 'the new homonormativity'. Something has changed in the way lesbians and gay men have been treated in many national con- 
texts over the last twenty years. Social norms around sexuality have undoubtedly shifted (however, partial, incomplete, and uneven that process might be). So, I have never disputed that a social phenomenon akin to 'homonormativity' has occurred over the last couple of decades. My work does, however, seek to challenge some of the ways in which Homonormativity has been theorized and the uses to which that theorization have been put. First, I don't think Lisa Duggan was suggesting that 'homonormativity' was an entirely new social phenomenon. There have always been social and sexual norms within lesbian and gay cultures and communities. What I think Duggan identified was that, around the turn of the century, some lesbians and gay men, particularly those seen to be in stable, romantic couples, had become incorporated within the bounds of what had previously been understood as exclusively heteronormativity - the social norms within Western societies which privilege certain forms of coupledom and sexual behaviour. At the same time, she identified the ways in which mainstream consumer capitalism (rather than just specialist businesses and services) was addressing LGBT consumers. While these two trends may well be linked, I think they get elided in problematic ways - stable, settled couples are said to be homonormative, but so too are those men and women who spend their time partying on a diminishing commercial scene - so homonormativity is imagined simultaneously to be marked by a flight from the commercial gay scene and lives spent immersed in it. I would suggest that, though these groups and the norms they live by overlap, they are quite distinct and deserve to be studied on their own terms. For example, the norms that are reproduced by two middle-aged suburban gay dads are not the same as those of men in their late twenties immersed in the clubbing and chemsex scenes (even though I acknowledge they might occasionally overlap more than many people would at first assume). It is relevant to research (and even critique) both those sets of norms, but if that is our only mode of enquiry; or a foundational aspect of what motivates our research; or, if we can only conceive of gay life through one of those two ideal types, then we risk overlooking many, many aspects of contemporary LGBT lives and the specific socio-spatial relationships that articulate them. As you say, homonormative can also be applied to any form of lesbian and gay political action that makes demands on and through the state. The slippage continues. So, again, we come back to the limits of queer and its celebration of the radically transgressive (which, of course, is not something that some of my earlier work was immune from). I don't want to study the normative at the expense of the transgressive (or vice versa); but I am interested in exploring the range of lives that sit between them, as well as exploring how both ends of that continuum might be more complex and contradictory than we might at first assume. 
In a (2012) paper I distinguished 'homonormativity' (the changing set of social relations by which certain expressions of homosexuality have become incorporated into mainstream socio-sexual norms alongside normative expressions of heterosexuality) from 'Homonormativity' (the theoretical response to those social changes). I think both need to be critiqued, but for different reasons. I think it is important to continue to think critically about homonormativity and to interrogate the new exclusions and other dilemmas that might accompany the normative celebration of stable, self-reliant, lesbian and gay couples. But I also think it is important to think critically about the ways in which these changes have been theorized as 'Homonormativity', and the ways in which that term has been deployed by activists and scholars alike. I think it is important to interrogate the social and geographical locations from which theorizations of Homonormativity have been written and to question, as I have done in some of my work (Brown 2012; 2015; 2019), whether it makes too many assumptions based on sexual politics and cultures in large North American metropolitan areas that do not play out in the same way in other national contexts, nor in cities and smaller towns lower down the urban hierarchy. In part, this is an appeal to study the functioning and implications of homonormativity in a wider range of settings and with greater geographical specificity. But it also stems from a concern that the lived experience of homonormativity is more complex, messy, and contradictory than many theorizations of Homonormativity might, at first, suggest. Finally, just as Jasbir Puar has repeatedly made clear that she never intended 'homonationalism' to be deployed as an accusation (Puar, 2017), I think too many uses of Homonormativity end up being used to dismiss or reject 'homonormative lifestyles' in ways that shut down conversations and fail to adequately engage with the everyday lives of most lesbians and gay men.

Gilly Looking geopolitically, how do you think gender fits within a sexualities perspective of global politics? What role do you think gender and sexuality, in particular, play in the world of governments and NGOs' international geopolitics? Or in other words, what makes 'states' act the way they do towards sexual and gender minorities and what do you think a geopolitical exploration can add to knowledge on sexualities and genders in local contexts?

Gavin I think there is no singular answer to this question. Typically, I think it is easier to make the case for equalities for sexual minorities where there is already a commitment to moving towards gender equality, but that is not always the case. Certainly a lot of the work that has been done, through the Yogyakarta Principles, to try and advance the case for human rights on the basis of sexual orientation and gender identities has sought to expand existing human rights law around sex 
and gender. That has seemingly made it easier for NGOs and other actors to claim that they are not seeking 'special rights' for LGBTQ+ people, but simply seeking to apply existing legislation and case law. But it is also the case that there are nation-states around the world that find it easier to justify some kind of protection for trans people, and facilitate gender reassignment, than they do to offer basic human rights to (lesbians and) gay men. So, I think what's useful is not to try and seek a golden rule connecting gender and sexuality in geopolitics, but to study the specific configurations of the politics of gender and sexuality in particular national contexts and to examine how that plays out relationally in their domestic and foreign policy, as well as examining how these configurations translate across spatial scales. Sometimes policies are developed (or promoted), in part, to distinguish one state from neighbouring states that are seen as geopolitical rivals (an example would be the way Israel presents itself as 'the only gay-friendly state in the Middle East'). At other times, policies are enacted or laws updated in order for a nation-state to present itself as not out of step with (or 'behind') its neighbours. There is an element of this in the recent recognition of the 'third gender' category in India, Bangladesh, and Pakistan. Policies are not just mobile, they sometimes seem to be (geopolitically) contagious.

One approach to these issues that has really inspired me recently, precisely because it looks at the specific dynamics of sexual and gendered politics in a given polity, is Heidi Nast's (2017) work on the market for sex dolls in Japan. This work skilfully weaves together attention to Japanese political economy, changing work cultures, demographic trends, geopolitics, and psychoanalytic interpretation to analyse the growing market for sex dolls amongst Japanese men. I think this offers a useful toolkit for multifactorial analysis of the geopolitics of sexuality and gender in other national contexts. Rather than just assessing whether policies are expressions of 'homonationalism', or critiquing colonial legacies (both of which have their place as analytical approaches), I think it is useful to also assess population trends and demographics; the specific influences (and reinterpretations) of cultural and religious traditions; the state of the national economy and the specific technical composition of the division of labour; the fault lines of social reproduction and care; the dominant form of the welfare regime; particular geopolitical tensions (at various spatial scales); the construction of nationalism and national identity; and how, together, these shape 'local' sexual and gendered identities, practices, and desires. This list might be lengthy, but it is not exhaustive. My message, I guess, is that we should have confidence in what a geographical analysis of sexualities and gender politics can offer.

Gilly Your work on the Non-Stop Picket of the South African Embassy in London centres on solidarity as an international social movement prac- 
tice and as a set of spatial relations. Within feminist thought, solidarity has been a very contested concept. Hemmings sees solidarity as an affective mode that helps move from an individual experience to a collective feminist capacity. That is, she prioritizes the understanding of difference within feminist politics and discusses reflexivity as a productive basis from which to seek solidarity with others based on "feeling the desire for transformation out of the experience of discomfort" (2012: 158). What social contexts make solidarity possible, and do you think that the underlying circumstances for solidarity can be achievable in other social movement contexts or in different locations?

Gavin Over the last decade or so I have been working with Helen Yaffe to examine the historical geography of the Non-Stop Picket of the South African Embassy in London in the late 1980s (Brown 2013; 2017; Brown and Yaffe 2014; 2017). The Non-Stop Picket was a continuous protest against apartheid in South Africa, which took place outside the South African embassy, 24 hours a day, for nearly four years. We were interested in the Non-Stop Picket for a range of reasons - to think about the spatialities of the protest itself; to think about the temporalities of it being 'non-stop'; but also to theorize how it practised solidarity with those resisting apartheid in Southern Africa in various ways.

The Non-Stop Picket came about in very particular circumstances. There had been an international campaign against apartheid since, at least, 1960. In the early 1980s, the African National Congress (ANC) and its allies in the international movement decided to make Nelson Mandela, and the demand for his unconditional release from jail, a central aspect of their campaigning. Although, in hindsight, there were real political problems with identifying a single individual as the synecdoche for a mass movement, this strategy also helped simplify the anti-apartheid message and made it far easier to recruit people to the cause internationally. The Non-Stop Picket both benefitted from this manoeuvre - its principal demand was the release of Mandela and the City of London Anti-Apartheid Group pledged to remain outside the embassy until Mandela was released - but it also reworked it, by offering solidarity to all those resisting apartheid in South Africa, not just those who were aligned with the ANC.

In the mid-1980s, mass resistance to apartheid (and the South African state's repression of that resistance) was a daily feature on the television news. It was difficult to ignore. The uprisings in South African townships in 1984-85 and other forms of mass resistance made South Africa appear increasingly ungovernable, and many people thought the end of apartheid regime was just around the corner. When, in February 1986, the South African activist Norma Kitson proposed a Non-Stop Picket until Mandela was released, I think she imagined that her group was committing to six months of protests. I don't think 
anyone imagined that the Non-Stop Picket would need to continue until early 1990.

In this context, I think the Non-Stop Picket offered British activists a way of acting in solidarity with anti-apartheid campaigners in South Africa, the chance to (help) make a real difference in the world, and the promise of an easy and significant victory. The fact that so many (mostly young) British activists chose to stand in solidarity with South Africans thousands of miles away cannot be separated from the string of defeats imposed on working class and progressive movements in Britain by the Thatcher government over the preceding few years. The hope of significant social change in South Africa seemed more realistic than in Britain at the time. At the same time, the City of London Anti-Apartheid Group made the case for anti-apartheid solidarity by emphasizing the (historic and on-going) links between Britain and South Africa - they argued that the same people who profited from apartheid in South Africa also benefited from racism in Britain. For them, acting in solidarity with anti-apartheid forces was not just about assisting distant others, it was fundamentally about reworking the political and economic connections between Britain and South Africa in the hope of enacting social change in both places.

Understood in this way, perhaps it's possible to think about how Clare Hemmings' approach to solidarity might be applied in this context. I think that for many people who ended up getting involved in the Non-Stop Picket their eventual political action was preceded by a powerful visceral reaction to seeing news coverage of the repression in South Africa. Seeing young black South Africans defending their communities with sticks, stones, and burning tyres against the armoured vehicles and weaponry of the South African Defence Force had a powerful affective impact on many young people in Britain and elsewhere. They reacted in anger, hurt, and horror. Perhaps they felt that 'something should be done' before they even contemplated that they should do something about apartheid. The Non-Stop Picket offered them the opportunity to do something about apartheid. In this regard, the Picket's location on a wide pavement in one of the busiest squares in central London was a distinct advantage. It made antiapartheid campaigning visible to people of all ages. While some future picketers went in search of the Non-Stop Picket having heard about it through other political campaigns they were involved with, many more stumbled across it incidentally whilst walking around Trafalgar Square and the West End of London for some other purpose. The non-stop ongoing-ness of the Non-Stop Picket also helped in this regard - repeated exposure to it made it easier for people to become convinced of its message. But the group also provided an active welcome to potential new recruits and offered them simple tasks to do in order to feel instantly connected to the protest. In these ways, the 
Non-Stop Picket helped assemble the atomized affective responses of individuals into a collective expression of solidarity.

I don't think this is what Clare Hemmings (2012: 158) means by building "transformation out of the experience of discomfort"; but for many participants in the Non-Stop Picket practising and sustaining solidarity involved overcoming a very British reticence about bending the rules of socially acceptable behaviour in public. The picket used its presence to disrupt the work of the South African Embassy and this meant singing, chanting, and making amplified speeches during the embassy's opening hours. Many of the songs that were sung on the picket were Zulu and Xhosa songs from the South African liberation movement. Learning to sing them usually meant learning the lyrics phonetically and taking on trust the translations that were provided. Many of the songs had dances or other moves associated with them, and many young activists had to overcome their embarrassment at singing and dancing on the streets. The picket frequently came into conflict with the police as well as supporters of the apartheid regime. Cultivating a vocal stance of righteous indignation in the face of racist assaults or unwanted police attention was another challenge for many; but once they grew confident in performing this response, it came to embody their solidarity in many ways.

All of this means that there were a complex set of different circumstances that came together to make the Non-Stop Picket work as a visible expression of transnational solidarity. It built upon the history, tactics, and legitimacy of a wider international anti-apartheid movement which had already been in existence for a quarter of a century. It was able to position itself as part of the most radical wing of that movement (and that certainly had an appeal to many young activists). More specifically, it drew on the tactical experience of the City of London Anti-Apartheid Group who had been regularly protesting outside the South African Embassy for the previous few years (and who had already defeated an attempt by the Metropolitan Police to ban protests outside the embassy). In all of this, they were aided by geopolitical events in South Africa which meant that apartheid was constantly in the news, its legitimacy was widely challenged, and the levels of protest in South Africa meant that victory looked possible. In London, the Non-Stop Picket was aided by the geographical location of South Africa House in Trafalgar Square - if the apartheid embassy had been tucked away in a side street, the protest would have been less visible and much harder to sustain. But, perhaps most importantly, the NonStop Picket mobilized thousands of people into active anti-apartheid solidarity because it offered them something to do and welcomed their involvement. Clearly, the exact circumstances in which this occurred are unlikely to be repeated, but I do not think that that means that such solidarity is impossible now. Indeed, as we explain in our book 
(Brown and Yaffe, 2017), many former anti-apartheid picketers have continued to apply some of the organizing principles of the Non-Stop Picket in other campaigns and solidarity movements over the last three decades. The conclusion to our book, Youth Activism and Solidarity (Brown and Yaffe, 2017: 212-219) sets out a series of political, tactical, and geographical lessons that we feel can be learned from the experience of the Non-Stop Picket.

Gilly Nine years passed between the publication of Geographies of Sexualities: Theory, Practice and Politics (2007) which you co-edited with Kath Browne and Jason Lim, and The Routledge Research Companion to Geographies of Sex and Sexualities (2016) which you co-edited with Kath Browne. Looking at these collections, can you point to a change in the ways we use, understand, and conceptualize geographies of sexualities? And looking through such historical lenses at the field of study, can you offer some thoughts about possible future directions for geographies of sexualities?

Gavin I think an honest answer to this question is probably that the differences between the two books reflect the development of our careers as much as they reflect changes in the field of the geographies of sexualities. When we edited Geographies of Sexualities (Browne et al., 2007), Kath, Jason, and I were all still early career academics. Indeed, I was still a PhD student when the manuscript was submitted and had just started my first academic post when the book was published. By the time we edited The Routledge Research Companion to Geographies of Sex and Sexualities (Brown and Browne, 2016), Kath and I were more established as mid-career academics. This probably impacted on our ambition and our confidence in what we could deliver and meant that we had had time to establish more extensive international networks from which to recruit contributing authors. Nevertheless, I think the way we approached the second book reflects both changes in the field of the geographies of sexualities and our vision of where the field could go. The range of contributors in the Routledge Research Companion is much more international (even though there are still huge gaps in its coverage). I think this suggests that geographers of sexualities are now working in a wider range of universities internationally and conducting research in a wider range of contexts; but it also perhaps draws attention to those contexts where it is still difficult to be taken seriously for doing this work. Of course, it also reflects some of the gaps in our networks, and also the fact that there are some amazing pioneering postgrads and early career researchers now beginning to make space for geographies of sexualities research in other national contexts whose work has only come to our attention since the book was commissioned. I hope that whoever edits the next major collection of geographies of sexualities research will be able to include authors from China, India, and other 
countries in Asia, as well as from places on the African continent outside of South Africa.

In the 2016 book we made a real effort to include more work on trans* lives around the world. I think this reflects the development of the sub-discipline. So I am pleased to see that geographers are beginning to do more work on the spatialities of lives lived across the LGBT spectrum. But I would like to see more work done on emerging sex and gender identities, such as asexuality, non-binary identities, and more. I really appreciate the work that Nick McGlynn is doing at the moment on 'bearspace' and I think there is real potential for geographers to examine new and emerging LGBT subcultures. At the same time, I remain disappointed that researchers who conduct critical work on heterosexual intimacies, relationships, and lifestyles so rarely identify their work as 'geographies of sexualities'. There are very obvious reasons why the field of geographies of sexualities has (mostly) been led by researchers from within the LGBT spectrum, but I think we limit the potential of the field if we only (or predominantly) study LGBT lives. As the boundaries of socio-sexual norms continue to change in many locations, I think it is useful to think across identity categories to think about the geographies of sexual and intimate lives in new ways.

Although our 2007 book contained chapters that addressed sexualities from a range of different perspectives, I think it is fair to say that most of the contributions to it could be considered as a subset of 'social and cultural geography'. With the Routledge Research Companion we consciously attempted to expand the scope of how geographies of sexualities might be conceived to include more work that was in dialogues with debates in political geography, critical geopolitics, health geographies, digital geographies, and more. I think some of this could have been pushed further. I think there is a lot more work to be done on the ways in which digital technologies continue to reshape how we experience our sexualities, and the ways in which apps orientate our sexualities in particular ways. So, I'm not sure this answer has offered a grand statement about future directions for the field of geographies of sexualities, but I have outlined a few areas where I think there is potential for the field to develop in interesting, productive, and timely ways.

Gilly What implications does the rise of the far right in so many countries have on the possibility of continuing the work of critical research and writing in academia?

Gavin The attacks on gender and sexualities studies in countries such as Brazil and Hungary, as well as the broader attacks on academic freedom and progressive, critical scholarship in many other locations is deeply worrying. In these contexts, individual academics need to make their own assessment of the professional, political, and personal risks they 
are prepared to take. More collectively, we need to work together to support and defend individual critical scholars, departments, and research centres that are under threat, and to defend the validity of critical scholarship on gender and sexuality. I think we need to mobilize our personal and professional networks, as well as our trade unions, to do this. You asked about solidarity earlier and I think this is a case where we need to put some of those lessons into practice. When friends and colleagues come under attack, we need to offer them support, but also take their lead on what kinds of solidarity and support are useful and will not exacerbate already intolerable or dangerous situations for them. But, I don't think we should wait to be asked for help, we should always let our colleagues know that we are there for them and ask what help they think would be useful.

Gilly Can you offer some advice to young scholars and articulate what you think is most important in doing good research and getting published in the field?

Gavin I think my headline piece of advice is to be pragmatic. And, in part, I say this because I think some of the rest of my advice might seem a little contradictory. On the whole, I think it is better to prioritize quality over quantity when it comes to academic publications. But, at the same time, I think it is important to fight perfectionism and to take a risk submitting work when it is 'good enough'. I have been publishing for about 20 years now. I'm fairly confident in the quality of my writing, but I still have a moment of anxiety and terror when I submit a paper for peer review (on the positive side, I also still feel excited each time something is published).

From my experience as a journal editor, I certainly have some suggestions that should help early career researchers survive the peerreview process and get published. First, think carefully about where you submit your work - are you confident that your work fits the aims and scope of your chosen journal? If in doubt, ask an editor for advice. It is usually a good idea to ensure that your work engages (where appropriate) with debates that have previously been covered in that journal and some relevant work that they have published previously.

Journal editors often struggle to recruit peer reviewers and you want the most appropriate people to review your work. Remember that when journals invite potential reviewers to read a submitted manuscript all they will usually see before they make a decision on whether to review it or not is the article's title and its abstract. So, make sure your title and abstract clearly communicate what your paper is about and the intellectual contribution that it makes. Make your abstract engaging, use it to draw first reviewers and, later (hopefully), other readers to it.

When writing a paper, have a really clear sense what it is about and how it makes a contribution to the field - although I know that, for 
me, clarity about what this is sometimes comes through the process of writing a paper and does not necessarily precede the writing process. State this contribution really clearly in the abstract, the introduction, and the conclusion. It can be very tempting to try and say too much in a single paper. Avoid this trap and try to focus on one main argument and a clearly articulated sense of what it adds to the field. Make sure that your theoretical framework actually aligns with the analysis of the empirical material you present.

Hopefully you receive constructive criticism from the peer reviewers and some clear guidance on how to navigate those reviews from an editor. Remember that you don't need to do everything that reviewers ask you to, but you will need to demonstrate to the editor that you have seriously considered those recommendations. Justify clearly and confidently to the editor the changes you have made and the ones you have not. Use the peer review process to help improve your paper; but do not over-rely on the process either. There is a fine line between submitting a paper that you hope is 'good enough' and expecting reviewers to resolve the problems with a paper you know has been submitted prematurely! Take advice, but not advantage.

I have said quite a lot here about making sure that your writing has a clear sense of its intellectual contribution. I think PhD students and other early career researchers sometimes over-estimate how much of a contribution a paper has to make. The trick is to be clear and confident about the ways in which your work has done something new (either theoretically, methodologically, or empirically), and why that matters.

Part of your question was about 'doing good research' and I think I want to finish my answer by saying that, for me, the most exciting research is that which takes me by surprise and offers me a new way of seeing something. I get bored of work that reproduces orthodoxies. For me, too much queer theorizing has become what Eve Sedgwick (and later JK Gibson-Graham) called 'paranoid thinking' - it already knows the answer to its research questions before the work is undertaken. As your question about the far right indicates, we live in difficult, dangerous, and challenging times and we need new ideas to rise to those challenges.

Gilly Finally, the question academics always ask each other: What are you working on now and what do you plan to do next?

Gavin I am working with Cesare Di Feliciantonio on a number of projects about the geographies and geopolitics of HIV in contemporary Europe. ${ }^{1}$ Cesare is particularly focused on migration within Europe by gay and bisexual men after they have received an HIV diagnosis. He

1. Editors' note: see Di Feliciantonio and Brown (2015) for an earlier collaboration. 
is thinking about how men move to access better health and social services, the role that stigma plays in these migrations, but also the ways in which some men take an HIV diagnosis as an opportunity for self-reinvention. Together we are thinking about how the uneven geographies of Pre-Exposure Prophylaxis (PrEP) as a pharmaceutical preventative method against HIV infection are impacting on gay and bisexual lives. In part this is thinking about the ways in which many men buy generic PrEP online or travel extra-territorially to access the medication and related health checks. But we are also interested in how access to PrEP and the ' $U=U$ ' message (that people with an undetectable viral load of HIV in their bloodstream cannot transmit the virus to others) is reshaping gay male culture.

At the moment, I am also hosting Dhiren Borisa from Delhi on a Visiting Fellowship through the Leicester Institute for Advanced Studies. He does amazing work on queer Dalit lives in India and I am hoping the three months he is spending in Leicester will lead to some ongoing research collaborations.

Together, these two collaborations (although quite different in focus) feed into my continuing interest in thinking about the geopolitics of sexuality and the possibilities for productive theoretical dialogues between critical and feminist geopolitics and the geographies of sexualities.

\section{Bibliographical references}

Bell, David (2001). "Fragments for a queer city". In: Bell, David; Binnie, Jon; Holliday, Ruth; Longhurst, Robyn and Peace, Robin (eds.). Pleasure Zones: Bodies, Cities, Spaces. Syracuse, NY: Syracuse University Press, 84-102.

Bell, David and Valentine, Gill (eds.) (1995). Mapping Desire: Geographies of Sexualities. London: Routledge.

BINNIE, Jon (1995). "Trading places: Consumption, sexuality and the production of queer space". In: Bell, David and Valentine, Gill (eds.). Mapping Desire: Geographies of Sexualities. London: Routledge, 166-181.

- (1997). "Coming out in geography: Towards a queer epistemology". Environment and Planning D: Society and Space, 15, 223-237. $<$ https://doi.org/10.1068/d150223>

BROWN, Gavin (2001). "Listening to queer maps of the city: Gay men's narratives of pleasure and danger in London's East End". Oral History Journal, 29 (1), 49-62.

- (2006). "Cosmopolitan camouflage: (Post-)gay space in spitalfields, East London". In: Binnie, Jon; Holloway, Julian; Millington, Steve and Young, Craig (eds.). Cosmopolitan Urbanism. London: Routledge, 130-145.

- (2008). "Urban (homo)sexualities: Ordinary cities and ordinary sexualities". Geography Compass, 2/4, 1215-1231. <https://doi.org/10.1111/j.1749-8198.2008.00127.x>

- (2009). "Thinking beyond homonormativity: Performative explorations of diverse gay economies". Environment and Planning A, 41, 1496-1510.

<https://doi.org/10.1068/a4162> 
- (2012). "Homonormativity: A metropolitan concept that denigrates 'ordinary' gay lives". Journal of Homosexuality, 59 (7), 1065-1072. <https://doi.org/10.1080/00918369.2012.699851>

— (2013). "Unruly bodies (standing against apartheid)". In: Cameron, Angus; Dickinson, Jen and Smith, Nicola (eds.). Body-States. Aldershot: Ashgate, $145-157$.

- (2015). "Rethinking the origins of homonormativity: The diverse economies of rural gay life in England and Wales in the 1970s and 1980s". Transactions of the Institute of British Geographers, 40 (4), 549-561.

<https://doi.org/10.1111/tran.12095>

- (2017). "Anti-apartheid solidarity in the perspectives and practices of the British far left in the 1970s and '80s". In: SMITH, Evan and WORLEY, Mathew (eds.). Waiting for the Revolution: The British Far Left from 1956. Manchester: Manchester University Press, 66-87. <https://doi.org/10.7765/9781526113672.00009>

- (forthcoming, 2019). "From nowhere: Provincializing gay life". Droits et Culture.

Brown, Gavin and Browne, Kath (eds.) (2016). The Routledge Research Companion to Geographies of Sex and Sexuality. London: Routledge. <https://doi.org/10.4324/9781315613000>

Brown, Gavin; Feigenbaum, Anna; Frenzel, Fabian and MCCrudy, Patrick (eds.) (2018). Protest Camps in International Context: Spaces, Infrastructures and Media of Resistance. Bristol, UK and Chicago, USA: Policy Press. <https://doi.org/10.1332/policypress/9781447329411.001.0001>

Brown, Gavin and YAFFE, Helen (2014). "Practices of solidarity: Opposing apartheid in the centre of London". Antipode, 46 (1), 34-52. $<$ https://doi.org/10.1111/anti.12037>

- (2017). Youth Activism and Solidarity: The Non-Stop Picket Against Apartheid, London: Routledge. <https://doi.org/10.4324/9781315738062>

Browne, Kath; Lim, Jason and Brown, Gavin (eds.) (2007). Geographies of Sexualities: Theory, Practices and Politics. Aldershot: Ashgate.

Campaign Choirs Writing Collective (2018). Singing for Our Lives: Stories from the Street Choirs. Bristol, UK: Hammeron Press.

Di Feliciantonio, Cesare and Brown, Gavin (2015). "Introduction: the sexual politics of austerity". Acme: an international e-journal for critical geographies, 14 (4), 965-974.

DUGGAN, Lissa (2002). "The new homonormativity: The sexual politics of neoliberalism". In: Castronovo, Russ and Nelson, Dana. Materializing democracy: Toward a revitalized cultural politics. Durham: Duke University Press, $175-194$. <https://doi.org/10.1215/9780822383901-007>

HarveY, David (1989). The Condition of Postmodernity: An Enquiry into the Origins of Cultural Change. Oxford: Blackwell.

Hemmings, Clare (2012). "Affective solidarity: Feminist reflexivity and political transformation”. Feminist Theory, 13 (2), 147-161. <https://doi.org/10.1177/1464700112442643>

Ingram, Gordon Brent; Bouthillette, Anne-Marie and Retter, Yolanda (eds.) (1997). Queers in Space: Communities/Public Places/Sites of Resistance. Seattle: Bay Press. 
NAST, Heidi J. (2017). "Into the arms of dolls: Japan's declining fertility rates, the 1990s financial crisis and the (maternal) comforts of the posthuman”. Social \& Cultural Geography, 18 (6), 758-785. <https://doi.org/10.1080/14649365.2016.1228112>

Oswin, Natalie (2018). "Society and space, here and now". Environment and Planning D: Society and Space, 36 (4), 613-616. <https://doi.org/10.1177/0263775818790806>

PuAR, Jusbir K. (2017). Terrorist assemblages: Homonationalism in queer times. Tenth Anniversary Expanded Edition. Durham: Duke University Press. <https://doi.org/10.1215/9780822371755> 